\title{
INFLUENCE OF PROTEIN DEFICIENCY AND SEX ON THE DEVELOPMENT OF OCULAR LESIONS AND SURVIVAL TIME OF THE VITAMIN A-DEFICIENT RAT*
}

\author{
BY \\ D. S. McLAREN $\dagger$ \\ Human Nutrition Research Unit, Nutrition Building, National Institute for Medical Research, \\ Mill Hill
}

\section{INTRODUCTION}

ATTENTION has recently been drawn to the frequent association of eye signs attributable to deficiency of vitamin A with systemic manifestations of protein malnutrition in children (McLaren, 1958). Whilst a deficiency of the vitamin in the diet would seem to be an adequate explanation, it is possible that the eye changes may result from an adverse effect of protein lack on one or more of the stages of vitamin A metabolism in the body.

This association is especially common in Indonesia, where de Haas, Posthuma, and Meulemans (1940) described 75 per cent. of their cases of xerophthalmia as having "general dystrophy"; Oomen (1953) and the writer (unpublished observations) found a similar percentage of kwashiorkor cases there with xerophthalmia and keratomalacia. From the same country has come a recent report (Yap-Kie-Tiong, 1956) suggesting that protein deficiency is responsible for the most severe degree of eye lesions classed as keratomalacia. This is based on a study of plasma protein and vitamin A determinations of ten children with xerophthalmia and ten with keratomalacia. Much turns upon the definition of the terms used and a division of cases into two such groups is arbitrary as the two conditions merge imperceptibly the one into the other. Furthermore, correlation between the estimations made and nutritional status is doubtful and control subjects were not used. It is possible to interpret the difference between the mean total protein values for the two groups as being an indication that the group with keratomalacia was eating a diet lower in protein than the other group. If so, then it might be reasonably argued that they might also be consuming less carotene and vitamin $\mathrm{A}$, thus accounting for the more advanced eye changes. That the patients with keratomalacia were much more seriously ill than the others is evident from the fact that they rarely survived more than a day or two after admission to hospital (Yap-Kie-Tiong, personal communication).

* Received for publication May 14, 1958.

+ Present address: East African Institute for Medical Research, Mwanza, Tanganyika. 


\section{Xerophthalmia and Dietary Protein}

The subject of the present study has not been approached in this way before, and the little work that has been done on the interrelationship of vitamin A and protein has not been designed to shed light on the human problem outlined above. Early French work (Randoin and Queuille, 1934) set out to show how the evolution of vitamin A deficiency is affected by the nature and the proportions of the protein in the diet. These workers concluded that protein has no effect on the development of xerophthalmia, but diets deficient in protein were not used, the levels being 17, 27, and 37 per cent.

About the same time there seems to have been a widely-held belief that it had been demonstrated that diets containing protein of poor quality and deficient in vitamin A caused xerophthalmia to develop more rapidly than those with good quality protein. This opinion is expressed by Parsons (1932) without giving his source, and according to Owen and Hennessey (1931-2) it appears in a text-book by McCollum and Simmonds (1929). It would seem that the source of this view is a paper by Powers, Park, and Simmonds (1923) which described the feeding of rats on three diets, all deficient in vitamin A and containing proteins of different qualities. These diets, however, were not equally deficient in the vitamin; for instance one of the two diets which contained casein had three times more casein than the other, and the rats receiving the diet with the greater amount of casein "came down more slowly with xerophthalmia". Protein was obviously not the only variable factor in these diets, and the conclusion that the quality of protein in a diet influences the onset of xerophthalmia cannot be accepted.

\section{Effect of Vitamin A on Growth and Protein Metabolism}

Vitamin A increases the efficiency of the food of rats in maintaining or producing tissues (Patterson, McHenry, and Crandall, 1942). Similarly, Mayer and Krehl (1948) found a reduction in the efficiency ratio of weight gain over food intake in vitamin A-deficient rats. That the rate of growth is closely related to the expenditure of vitamin A was shown by Johnson and Baumann (1948). Rats deprived of vitamin A and restricted in growth by inadequacy of calories, or of tryptophan or thiamine, used up their stores less rapidly than those which were lacking vitamin A alone. In a study of the nitrogen metabolism of young and adult rats suffering from vitamin Adeficiency, Brown and Morgan (1948) found impaired growth, increased urinary nitrogen, and disturbed nitrogen balance in young but not in adult animals. They concluded that vitamin A is essential for tissue protein growth but not for its maintenance. Dye, Bateman, and Porter (1945) found that lack of protein had little effect on the utilization of vitamin A in the rat. The levels of protein they employed were 9,18 , and 36 per cent. 
Finally, Moore, Sharman, and Ward (1952), in a preliminary investigation, found that liberal doses of vitamin A enabled rats to subsist better on a diet deficient in protein.

It is evident from these various investigations of this aspect of the metabolism of vitamin A that a good deal is known about it in the rat, but no other animal appears to have been used and in no instance have the eye lesions been considered at the same time.

\section{Influence of Sex on Vitamin A Requirements}

After the first world war an epidemic of night blindness and xerophthalmia occurred in Vienna, and some time later Birnbacher (1928) produced statistics which showed that 88.5 per cent. of the patients he studied had been men and boys. A recent study in Java, where xerophthalmia is endemic, shows that there is a male preponderance, especially after the age of 10 years (Oomen, 1958). In Birnbacher's series there had also been the greatest disparity between the sexes after the age of 10 years and maximum from 20 to 25 years. Even so, of the 22 cases under 10 years of age, seventeen were boys.

In rats, Coward, Key, Dyer, and Morgan (1931) found that, when young rats which were deficient in vitamin A were given large doses of cod-liver oil, males grew more rapidly than females, but that at low levels of dosing the relationship was reversed. Later, from a large accumulation of data, Coward (1942) showed that there was a statistically highly significant greater mortality amongst males.

Evidence whether males deprived of vitamin A show signs of deficiency before females is inconclusive, for Mayer and Krehl (1948) claimed that this was so for rats, but Booth (1952) could not confirm this.

\section{Present InVestigations}

Methods. - Wistar albino rats, known as "Glaxo" as they had been obtained 7 years previously from Glaxo laboratories and bred in the Human Nutrition Research Unit, were used throughout. Egg albumen was chosen as the sole source of protein, being free from vitamin $A$, and avidin inhibition of biotin was prevented by heat treatment. Each constituent of the diets was subjected to the Carr-Price test and shown to contain no vitamin A.

Because of the large liver stores of the vitamin which young animals possess, it is necessary to induce deprivation very early if signs of deficiency are to be manifested in the growing animal. If the deficient régime is commenced before conception or in early gestation in the rat congenital defects are frequently produced. It is sufficiently early to start to feed the dam a diet free from vitamin A during lactation. In the experiments to be described a deficient diet (Diet 1) was fed from the 16th day of life of the young, to both the dam and the young, and weaning took place 7 days later. This diet was composed as follows : 


\begin{tabular}{lll|c}
\hline \multicolumn{2}{c|}{ Ingredient } & & Per cent. \\
\hline Egg albumen & $\ldots$ & $\ldots$ & 18 \\
Wheat starch & $\ldots$ & $\ldots$ & 53 \\
Cotton seed oil & $\ldots$ & $\ldots$ & 10 \\
Yeast .. & $\ldots$ & $\ldots$ & 15 \\
Salt mixture &. &.. & 4 \\
\hline
\end{tabular}

On weaning, rats were kept in individual cages and provided ad libitum with both food and water. Their eyes were examined by the slit-lamp microscope twice weekly. On occasion, fluorescein 2 per cent and azur II 0.5 per cent. were used to aid the location of lesions of the cornea.

36 rats were used from six litters, three males and three females in each. At weaning one male and one female rat from each litter were taken at random and fed Diet $2,3,4$, or 5 , so that one male and one female rat from each litter received Diet 2 and similarly with Diet 3, but only one male and one female rat from each of three litters received Diet 4 and Diet 5. The four diets 2-5 were composed as follows:

\begin{tabular}{|c|c|c|c|c|c|c|}
\hline \multirow{2}{*}{\multicolumn{3}{|c|}{$\begin{array}{l}\text { Ingredient } \\
\text { (per cent.) }\end{array}$}} & \multicolumn{4}{|c|}{ Diet } \\
\hline & & & 2 & 3 & 4 & 5 \\
\hline $\begin{array}{l}\text { Egg albumen } \\
\text { Wheat starch } \\
\text { Cotton seed oil } \\
\text { Salt mixture. . }\end{array}$ & $\begin{array}{l}\cdots \\
\cdots \\
\cdots \\
\cdots\end{array}$ & $\begin{array}{l}\cdots \\
\cdots \\
\cdots \\
\cdots\end{array}$ & $\begin{array}{r}18 \\
68 \\
10 \\
4\end{array}$ & $\begin{array}{r}11 \\
75 \\
10 \\
4\end{array}$ & $\begin{array}{r}6 \\
80 \\
10 \\
4\end{array}$ & $\begin{array}{r}4 \\
82 \\
10 \\
4\end{array}$ \\
\hline
\end{tabular}

The following quantities of vitamins were intimately mixed with each kilogram of the above diets:

\begin{tabular}{|c|c|}
\hline Vitamin & g. \\
\hline 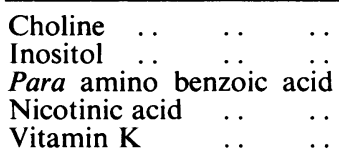 & $\begin{array}{l}1.0 \mathrm{gm} . \\
1.0 \\
0.3 \\
0.1 \\
0.01\end{array}$ \\
\hline
\end{tabular}

Other vitamins were given as an oral mixture; the following vitamins were made up in $7.6 \mathrm{ml}$. distilled water and $0.1 \mathrm{ml}$. was given to each rat four times a week:

\begin{tabular}{lll|l}
\hline \multicolumn{2}{c|}{ Vitamin } & mg. \\
\hline Thiamine .. &. &. & 2 \\
Riboflavin &. &.. & 2 \\
Pyridoxine &. &.. & 1 \\
Pantothenic acid . &.. & 5 \\
Folic acid &. &.. & 3 \\
Biotin .. &. &. & 0.3 \\
B12 &. &.. & 0.05 \\
Ascorbic acid &.. &.. & 20 \\
\hline
\end{tabular}


Because of its well-known sparing effect on vitamin A, vitamin E was not added to the diet. Evidence that this may have influenced the results with the rats on Diets 4 and 5 will be presented later.

Results.-Typical growth curves of rats on Diets 2, 3, and 5 are shown in the Figure. Those animals receiving 18 per cent. protein grew normally until about 60 or 70 days of age, when growth slowed down, ceased for several days, and was followed by rapid loss of weight and general deterioration. That this was due to the vitamin A stores having been exhausted was confirmed by the appearance of clinical signs of vitamin A deficiency, including xerophthalmia, shortly afterwards. Rats on 11 per cent. protein grew less well but otherwise behaved similarly, whilst those on 4 per cent. protein failed to grow at all and maintained almost constant body weight until they died, usually at about 80 days of age.

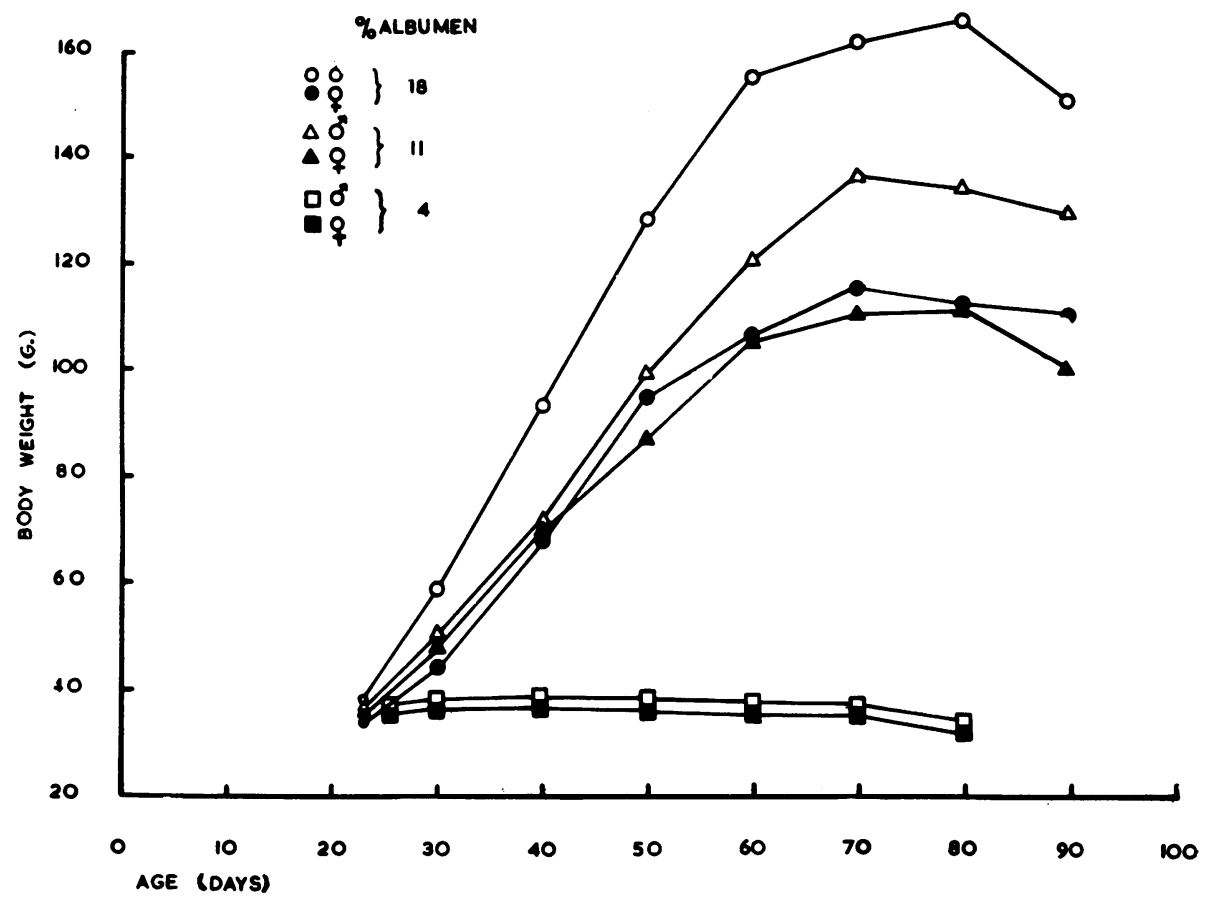

FIGURE.-Growth of rats on diets 2, 3, and 5 .

(Vitamin A-free and different levels of egg albumen).

The Table (opposite) shows the weaning weight, growth rate from weaning until the maximum weight was reached, time of onset of xerophthalmia, and survival time of each rat.

Rat No. 108 had severe diarrhoea from weaning, failed to eat much of the diet, grew poorly, and died early. It has consequently been disregarded. 
TABLE

DETAILS OF RATS FED ON DIETS DEFICIENT IN VITAMIN A AND WITH DIFFERENT LEVELS OF PROTEIN

\begin{tabular}{|c|c|c|c|c|c|c|c|}
\hline $\begin{array}{l}\text { Litter } \\
\text { No. }\end{array}$ & $\begin{array}{l}\text { Rat } \\
\text { No. }\end{array}$ & Sex & $\begin{array}{l}\text { Per cent. } \\
\text { Protein } \\
\text { in Diet }\end{array}$ & $\begin{array}{l}\text { Growth Rate } \\
\text { (g./day) }\end{array}$ & $\begin{array}{c}\text { Time of Onset } \\
\text { of Xeroph- } \\
\text { thalmia (days)* }\end{array}$ & $\begin{array}{l}\text { Time of } \\
\text { Survival } \\
\text { (days)* }\end{array}$ & $\begin{array}{c}\text { Weaning } \\
\text { Weight } \\
\text { (g.) }\end{array}$ \\
\hline \multirow{3}{*}{1} & $\begin{array}{l}70 \\
74\end{array}$ & $\underset{f}{m}$ & $\begin{array}{l}18 \\
18\end{array}$ & $\begin{array}{l}3 \cdot 3 \\
1 \cdot 8\end{array}$ & $\begin{array}{l}41 \\
62 \dagger\end{array}$ & $\begin{array}{l}69 \\
62\end{array}$ & $\begin{array}{l}37 \cdot 5 \\
33 \cdot 5\end{array}$ \\
\hline & $\begin{array}{l}71 \\
75\end{array}$ & $\underset{f}{m}$ & $\begin{array}{l}11 \\
11\end{array}$ & $\begin{array}{l}2 \cdot 4 \\
1 \cdot 4\end{array}$ & $\begin{array}{l}71 \\
57\end{array}$ & $\begin{array}{l}76 \\
80\end{array}$ & $\begin{array}{l}38 \\
38\end{array}$ \\
\hline & $\begin{array}{l}72 \\
73\end{array}$ & $\underset{f}{m}$ & $\begin{array}{l}4 \\
4\end{array}$ & - & $\begin{array}{l}54 \dagger \\
59 \dagger\end{array}$ & $\begin{array}{l}54 \\
59\end{array}$ & $\begin{array}{l}39 \cdot 5 \\
39\end{array}$ \\
\hline \multirow{3}{*}{2} & $\begin{array}{l}79 \\
76\end{array}$ & $\underset{f}{m}$ & $\begin{array}{l}18 \\
18\end{array}$ & $\begin{array}{l}2 \cdot 0 \\
1 \cdot 2\end{array}$ & $\begin{array}{l}78 \dagger \\
76\end{array}$ & $\begin{array}{l}78 \\
96\end{array}$ & $\begin{array}{l}43 \\
26 \cdot 5\end{array}$ \\
\hline & $\begin{array}{l}80 \\
77\end{array}$ & $\operatorname{m}_{f}$ & $\begin{array}{l}11 \\
11\end{array}$ & $\begin{array}{l}1 \cdot 6 \\
1 \cdot 1\end{array}$ & $\begin{array}{l}74 \\
85\end{array}$ & $\begin{array}{l}85 \\
86\end{array}$ & $\begin{array}{l}26 \cdot 5 \\
39\end{array}$ \\
\hline & $\begin{array}{l}81 \\
78\end{array}$ & $\mathrm{~m}$ & $\begin{array}{l}4 \\
4\end{array}$ & $\overline{-}$ & $\begin{array}{l}58 \dagger \\
36 \dagger\end{array}$ & $\begin{array}{l}58 \\
36\end{array}$ & $\begin{array}{l}40 \cdot 5 \\
37 \cdot 5\end{array}$ \\
\hline \multirow{3}{*}{3} & $\begin{array}{l}85 \\
82\end{array}$ & $\underset{f}{m}$ & $\begin{array}{l}18 \\
18\end{array}$ & $\begin{array}{l}2 \cdot 1 \\
1 \cdot 7\end{array}$ & $\begin{array}{l}66 \\
67\end{array}$ & $\begin{array}{l}69 \\
68\end{array}$ & $\begin{array}{l}35 \cdot 5 \\
33 \cdot 5\end{array}$ \\
\hline & $\begin{array}{l}86 \\
84\end{array}$ & $\underset{f}{m}$ & $\begin{array}{l}11 \\
11\end{array}$ & $\begin{array}{l}1 \cdot 7 \\
1 \cdot 3\end{array}$ & $\begin{array}{l}68 \dagger \\
73\end{array}$ & $\begin{array}{l}68 \\
73\end{array}$ & $\begin{array}{l}34 \cdot 5 \\
34\end{array}$ \\
\hline & $\begin{array}{l}87 \\
83\end{array}$ & $\underset{f}{m}$ & $\begin{array}{l}4 \\
4\end{array}$ & - & $\begin{array}{l}66 \dagger \\
46 \dagger\end{array}$ & $\begin{array}{l}66 \\
46\end{array}$ & $\begin{array}{l}35 \\
30 \cdot 5\end{array}$ \\
\hline \multirow{3}{*}{4} & $\begin{array}{l}100 \\
103\end{array}$ & $\underset{f}{m}$ & $\begin{array}{l}18 \\
18\end{array}$ & $\begin{array}{l}2 \cdot 0 \\
1 \cdot 1\end{array}$ & $\begin{array}{l}60 \\
75\end{array}$ & $\begin{array}{l}63 \\
93\end{array}$ & $\begin{array}{l}41 \cdot 5 \\
45 \cdot 5\end{array}$ \\
\hline & $\begin{array}{l}102 \\
105\end{array}$ & $\underset{f}{m}$ & $\begin{array}{l}11 \\
11\end{array}$ & $\begin{array}{l}1 \cdot 6 \\
1.4\end{array}$ & \multicolumn{2}{|c|}{${ }_{62}^{\text {Given vit. A }} 81$} & $\begin{array}{l}43 \\
44 \cdot 5\end{array}$ \\
\hline & $\begin{array}{l}101 \\
104\end{array}$ & $\underset{f}{m}$ & $\begin{array}{l}6 \\
6\end{array}$ & 二 & $\begin{array}{l}44 \dagger \\
44 \dagger\end{array}$ & $\begin{array}{l}44 \\
44\end{array}$ & $\begin{array}{l}45 \\
43 \cdot 5\end{array}$ \\
\hline \multirow{3}{*}{5} & $\begin{array}{l}106 \\
109\end{array}$ & $\underset{\mathrm{f}}{\mathrm{m}}$ & $\begin{array}{l}18 \\
18\end{array}$ & $\begin{array}{l}2 \cdot 5 \\
1 \cdot 8\end{array}$ & $\begin{array}{l}62 \\
55\end{array}$ & $\begin{array}{l}66 \\
77\end{array}$ & $\begin{array}{l}46 \\
40\end{array}$ \\
\hline & $\begin{array}{l}108 \ddagger \\
111\end{array}$ & $\underset{f}{m}$ & $\begin{array}{l}11 \\
11\end{array}$ & $\overline{1 \cdot 2}$ & \multicolumn{2}{|c|}{$\overline{\text { Given vit. A }}$} & $\begin{array}{l}45 \cdot 5 \\
43 \cdot 5\end{array}$ \\
\hline & $\begin{array}{l}107 \\
110\end{array}$ & $\mathrm{~m}$ & $\begin{array}{l}6 \\
6\end{array}$ & E & $\begin{array}{l}67 \dagger \\
57 \dagger\end{array}$ & $\begin{array}{l}67 \\
57\end{array}$ & $\begin{array}{l}49 \\
41 \cdot 5\end{array}$ \\
\hline \multirow{3}{*}{6} & $\begin{array}{l}112 \\
115\end{array}$ & $\underset{f}{\mathrm{f}}$ & $\begin{array}{l}18 \\
18\end{array}$ & $\begin{array}{l}2 \cdot 6 \\
1 \cdot 4\end{array}$ & $\begin{array}{l}46 \\
69\end{array}$ & $\begin{array}{l}77 \\
70\end{array}$ & $\begin{array}{l}38 \\
37\end{array}$ \\
\hline & $\begin{array}{l}113 \\
116\end{array}$ & $\underset{f}{m}$ & $\begin{array}{l}11 \\
11\end{array}$ & $\begin{array}{l}1.7 \\
1.0\end{array}$ & $\begin{array}{l}53 \\
61\end{array}$ & $\begin{array}{l}69 \\
78\end{array}$ & $\begin{array}{l}36 \cdot 5 \\
35 \cdot 5\end{array}$ \\
\hline & $\begin{array}{l}114 \\
117\end{array}$ & $\underset{f}{m}$ & $\begin{array}{l}6 \\
6\end{array}$ & - & \multicolumn{2}{|c|}{$\begin{array}{l}\text { Given vit. A } \\
\text { Given vit. A }\end{array}$} & $\begin{array}{l}36 \\
37\end{array}$ \\
\hline
\end{tabular}

* Reckoned from 16th day of life when vitamin A-free regime commenced.

t Survived this number of days without xerophthalmia developing.

† Sick animal ; disregarded. 
Nos. 102 and 111 were given liberal doses of vitamin A after they had reached maximum weight but before eye signs had developed. Both of these rats, and also Nos. 114 and 117, also given vitamin A, increased in weight after dosing; they survived for several months and eye signs did not develop, indicating that the eye changes in the other animals were due to deficiency of vitamin A.

\section{Discussion}

\section{(1) Influence of Protein Deficiency on Onset of Xerophthalmia and Survival Time}

(a) All rats on Diets 2 and 3, except those which were given vitamin A, developed xerophthalmia, whilst none of those on Diets 4 and 5 did so. Whilst some of those animals on the 4 and 6 per cent. protein diets died before those on the higher levels of protein were beginning to develop eye signs, nevertheless many lived sufficiently long for xerophthalmia to have developed if the level of protein had not been exerting an influence. It was realized that the absence of vitamin $\mathrm{E}$ might have accounted for the early death of these rats on low levels of protein, as this effect is known to occur (Dam, 1944). Consequently a further litter of six rats, three males and three females, was treated as before, being given a 4 per cent. protein diet free from vitamin A but with added vitamin E. They all lived to be about 140 days old when they were killed, without any having developed eye signs.

It may then be concluded that, under the conditions of the present experiments, protein deficiency did not hasten the onset of xerophthalmia, but rather that, in the presence of marked growth retardation due to protein lack, the onset of signs was delayed. This was possibly due to the liver stores being used up less quickly than when there was adequate protein and initial growth was rapid.

(b) The survival time of rats on 18 per cent. protein was a mean value of 74 days from receiving the experimental diet (Diet 1) and $77 \cdot 3$ days in the case of 11 per cent. protein group. This difference is not significant $(P \simeq 0 \cdot 25)$, but the slightly longer survival of those rats which grew less well is compatible with the evidence that vitamin A stores are used up in proportion to growth.

\section{(2) Influence of Sex on Onset of Xerophthalmia and Survival Time}

(a) Excluding the three male and two female rats which died before xerophthalmia developed, and those on 4 and 6 per cent. levels of protein, none of which showed eye signs, eight male and ten female animals remain to be compared.

The mean number of days for the onset of xerophthalmia in the two sexes is 59.125 and 68.0 days respectively. This difference is highly significant $(P<0.01)$, and because of the greater growth rate of the male, also supports 
the view that rate of growth determines the period of exhaustion of vitamin A stores.

(b) To investigate the effect of sex on survival time ten male and eleven female rats were available for comparison and the mean survival in days from the day of starting on the experimental diet (Diet 1) is 72.0 for males and 78.56 for females. This difference is also highly significant $(P<0.01)$ and may also be related to the different rate of growth of the two sexes. This is supported by the fact that this effect of sex was reversed in the case of the rats on the low protein diets in which almost no growth took place, and where the males survived considerably longer than the females. This may have been due to some selective effect of vitamin E deficiency upon females but the numbers are small.

\section{SUMMARY}

Albino rats were fed diets free from vitamin $\mathrm{A}$ and containing different percentages of protein. Deficiency of protein did not hasten the onset of xerophthalmia, and when the deficiency was severe the development of eye signs was delayed. Female rats took longer to develop xerophthalmia and survived longer than male rats.

The relationship of these results to the rate of growth and using up of the body stores of vitamin $\mathrm{A}$ is discussed.

This work was undertaken whilst the writer was a Colonial Medical Research Student and formed part of a thesis submitted in partial fulfilment of the requirements for the degree of Ph.D., University of London. The writer wishes to acknowledge the constant help and interest of the Director of the Human Nutrition Research Unit, Medical Research Council, Professor B. S. Platt, C.M.G.

\section{REFERENCES}

Birnbacher, T. (1928). Münch. med. Wschr., 75, 1114.

BOOTH, V. H. (1952). J. Nutr., 48, 13.

Brown, E. F., and Morgan, A. F. (1948). Ibid., 35, 425.

COWARD, K. H. (1942). Brit. med. J., 1, 435. , KeY, K. M., Dyer, F. J., and Morgan, B. G. E. (1931). Biochem. J., 25, 551.

DAM, H. (1944). Proc. Soc. exp. Biol. (N.Y.), 55, 55.

De HaAs, J. H., Posthuma, J. H., and Meulemans, O. (1940). Geneesk. T. Ned.-Ind., $80,928$. Dye, M., Bateman, I., and Porter, T. (1945). J. Nutr., 29, 341.

Johnson, R. M., and Baumann, C. A. (1948). Ibid., 35, 703.

MAYER, J., and KREHL, W. A. (1948). Yale J. Biol. Med., $20,403$.

McCollum, E. V., and Simmonds, N. (1929). "The Newer Knowledge of Nutrition", 4th ed. p. 165. Macmillan. New York. Cited by Owen and Hennessey (1932).

McLaren, D. S. (1958). Bull. Wld Hlth Org., 19, 303.

Moore, T., Sharman, I. M., and WARD, R. J. (1952). Biochem. J., 52, xii.

OOMEN, H. A. P. C. (1953). Bull. Wld Hlth Org., 9, 371. (1958). Proc. Nutr. Soc., 17, viii.

OWen, H. B., and HenNeSSEY, R. S. F. (1932). Trans. roy. Soc. trop. Med. Hyg., $25,367$.

Parsons, L. G. (1932). Amer. J. Dis. Child, 43, 1293.

Patterson, J. M., Mchenry, E. W., and Grandall, W. A. (1942). Biochem. J., $36,792$.

Powers, G. F., Park, E. A., and Simmonds, N. (1923). J. biol. Chem., 55, 575.

RANDOIN, L., and Queuille, S. (1934). C. R. Acad. Sci. (Paris), 198, 1942.

YAP-KIE-Tiong (1956). Brit. J. Ophthal., 40, 502. 